\title{
ANNOUNCEMENTS
}

\section{I 名誉会員の訃報}

本学会名誉会員冲中重雄先生には, 1992 年 4 月 20 日, 川崎市虎の阴病院分院にて死去されるし た.ここに䔆んで哀悼の意を表します。

(理事長 三輪史朗)

\section{II 本学会会員の受賞}

本学会会員, 日本大学医学部教授北川照男氏は 1992 年春, 紫綬褒章を受章さ机ました。ここに本 学会を代表し，招祝い申し上げます。

(理事長 三輪史朗)

\section{III 学会賞選考委員会}

1992（平成 4) 年度 人類遗伀学会賞和よび奨励賞の選考委員会が，本年 3 月 13 日に東京で開催さ れた。本学会評議員および名誉会員上り推薦の西った候補者について慎重審議の結果; 大阪大学細胞 工学センター教授 田中龟代次氏の「A 群色素性乾皮症遗伝子のクローニングとその修復機構の解 析」に対し，第 25 回日本人類遗伝学会賞が贈られることになった。さらに，東北大学医学部助教授 松原洋一氏が，「中鎖アシル CoA 脱水素醇素欠損症の分子遗伝学的研究」によって，第 4 回日本人 類遗伝学会獎励賞を受賞することとなった。

(庶務幹事 池内達郎)

\section{IV 第 8 回国際人類遺伝学会議出席報告書}

第 8 回国際人類遺伝学会議は，1991 年 10 月 7 日 11 日の 5 日間，米国ワシントン D.C. に おいて開催された，会議の概要については，本誌 36 巻 4 号の 347 348 頁に紹介されている.

同会議化は，以下の 5 会員が日本人類遺伝学会よりの旅費補助を引けて出席し，研究発表を行っ た. 德永勝士（東京大・輸血部），吉田光明（東京医科歯科大・難治研），大野耕策（鳥取大・脳神経 小児科)，遠藤文夫 (熊本大・小児科)，福嶋義光（埼玉小児医療セ）で苛る．以下飞出席報告書を掲 載する。

\section{1. 東京大学医学部附属病院輸血部助手 : 徳永勝士}

\section{[研究発表の内容]}

a) Distribution of MHC haplotypes in East Asia and multiple migration routes of the ancestral populations.

本演題はポスター演題として受理されたが，座長の判断により，ワークショップ “Genetic Variability and Population Differentiation”でも口演を求められた。

はじめに，MHC ハプロタイプがさまざすな人類集団を特徵づける極めて有用なマーカーとなりら る主な根赵を述べを.とくに，パルスフィールド電合泳動法を用いた physical mapping，その他の 分子レベルの証樾から，それぞれの MHCハプロタイプが人類進化を通して，そのゲノム構成をよく 保ってきたと考光られることを强調した。つぎに，日本人 460 家系，中国人 100 家系，韓国人 30 家系から成る大視模な家系試料について, HLA クラス I, II, III の調查を行った結果を報告した. MHC ヘプロタイプのレベルからみれば，3 集団間炕は明瞭な差異が存在しまた日本の地域集団間 


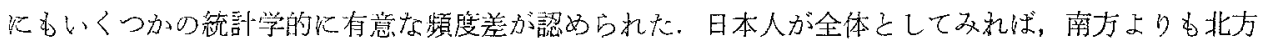
の東アジア集団以近く，また 3 集団間の関保炕ついて﨡，韓国人が日本人と中国人の中間炕位置し，

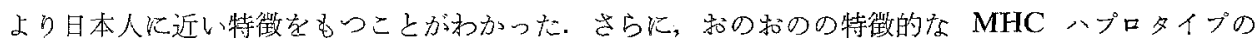
分布より，東アジア諸集団の形成にあずかった先祖集団の拡散と移住について，複数の異なるルート 老推定することができた。

上記演題の他に，以下の 2 題のボスター発表に共同研究者として加わった。

b) Molecular analysis of the Japanese haplotypes carrying duplicated $\mathrm{C} 4 \mathrm{~A}$ genes.

c) MHC susceptibility genes of rheumatoid arthritis in Japanese.

演題 b) では，日本人で頻度の高い2 種の MHC八ブロタイプが補体 C4A の遺伝子重複をるつ ことを述べた。これらの重複領域の構成について，新しいクラス而遺伝子のひとつ RD などのクラ ス皿遺伝子群のプローブを用いた RFLP 解析に加え，パスフィールド電気泳動法や，FCR 法希利

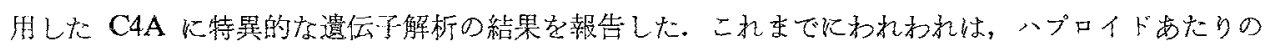
$\mathrm{C} 4 \mathrm{~A}$ 遺伝子の数が 0 個から 4 個までの寸べてのタイブを観察しておら，この上らな遺伝子の数の 变異の機能的意義や莫の発生機構の解明索目指している.

演題 C)では, 日本人の慢性関節りウマチに対して, MHC 領域化 2 種の感受性遗伝子が㐫るこ 々を提晿した，第 1 が，HLA-DRB1 鎖の 70〜74 番のアミノ酸であり，発症のメカニズムとして “molecular mimicry”が支持されることを，PCR 法に上る解析，配列木モロジー検索，合成ペプチ ドに対する抗体アッ七イなどの結果から示した，第2の感受性遺伝子としてC4A*QO か, これに 強く関連する遺伝子が考光られた。予備調查の結果， $C 4 A^{*} Q 0$ 叔よび $C 4 B^{*} 5$ (第 1 の遗伝子と八 プロタイプを形成する）の有無による患者のグループ分けが，多変量解析を用いた臨床症状火上る分 類によく対応した。

[発表演題に対する討論と反応] 演題 a) に関して，多数の家族から血液試料を得て行った MHC 八プロタイプの分布調查に評価が与光られた．東アジアに执いて，複数の先祖集団がいくつかの異な るルートを経て移住, 混血したという推定は, 形態学的研究から得られる結果とも拈和さ权一致して 扣り，大い《興味を持た机た。一方，HLA 《は方種の自然淘汰が働いて扣り，人類集団の類縁性 や形成過程の推定に用いるのにふさわしいマーカーであるのかという疑問も提出された，現在われわ れはこれに剂して明確答点られないが，HLA の機能(多種多様な外来めるいは自己の抗原ぺプチ ドを T 細胞化提示する)から考克て, 特定の対立遺伝子たけが強く選択されることは起こりにくく， また経験的にもHLA 対立遺伝子やハプロタイプから推定される類縁性は他の遺伝子マーカーからの

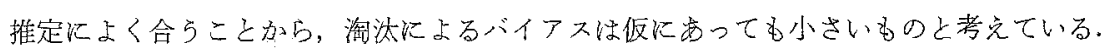

[関連する他の研究発表の状況] ワータショップでは, Serjeantson (Austr. Nat1. Univ., Canberra) が太平洋の諸集団㶤ついて，HLA クラス川遺伝子群のハプロタイプ分布を報告し，これらの集団の 類縁性について考察した. 票た, Chakraborty (Univ. Texas Health Sci. Cent., Houston) は, VNTRや Microsatellite などの槀度な多型性を示す遗伝マーカーを集団調查に用いる場合の注意点

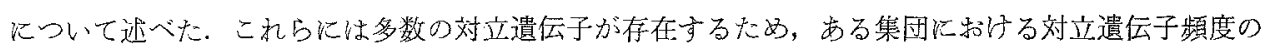
分布を正確以推定するためには大きな規模の集団調査をしなければならないまた従来推定值と観察 值との適合性の検定によく用いられてきた $\chi^{2}$ テストは，十分な感度を持たないことにも言及した。 実祭 Jenkins (South Afr. Inst. Med. Res., Johannesburg) む, 従来の遺伝マーカーの結果と異な る奇妙な結果をVNTRで認めている.

また演題 b) 飞関溥して，Yu b (Ohio State Univ., Columbus) がC4 遺伝子のすぐ上流に新し い遺伝子が存在し，しかも $C 4$ と间様にこ机らも重複している（RP1 和よび $R P 2$ と命名）ことを 
見いだした。最近 MHC のクラス而領域には新しい遗伝子が次々に発見されて呿り，しかもその多 くに遺伝子重複がみられることは與味深い。これらの遺伝子の機能の解明と疾患感受珄への関与は今 後の重要な研究課題のひとつであうう.

\section{2. 東京医科歯科大学難治疾患研究所遺云疾患研究部門 (細胞遗伝) 助手 : 吉田光明}

Suppression of cell growth in a human renal carcinoma cell line by introduction of a $¥ 3 p$ chromosome via microcell-fusion.

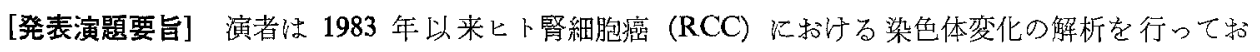
り，\#3 染色体短腕（\#3p）の構造異常（欠失，不均衡転座飞上る部分欠失）が，本疾患飞特異的な染 色体異常であることを見いだしたこの異常はその後国外の解析に括いても追認され， RCC 発生に

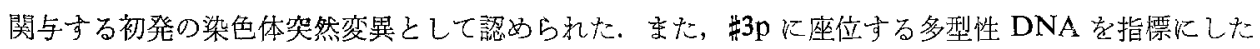
尰湯の DNA 解析火拈いて子 loss of heterozygosity (LOH) が高頻度飞認められ, 部分欠失の存在 が示されふ。これらの細胞遗伝学的ならびに分子遺伝学的解析の結果, \#3p の久失領域に RCC の発 生飞関連した癌抑制遺伝子の存在が想定され，網膜芽細胞腫やウイルムス腫瘍で提唱された癌抑制遺

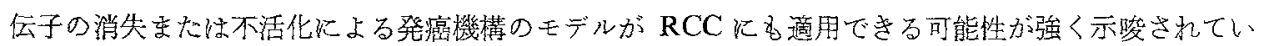
る.

本研究では，\#3p に和々る癌抑制遗伝子の存在とその嗹瘍細胞に対する增殖抑制効果を検証するた め, 演者らが樹立した腎細胞癌の長期培養細胞（MRI-23）飞微小核細胞融合法を用いて, 正常線維芽 細胞由来の \#3p 導入し, その細胞生物学的影響解析した。融合に用いた親細胞 MRI-23には,

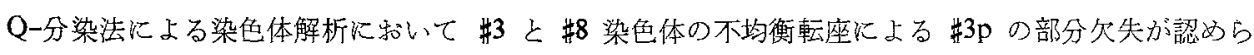

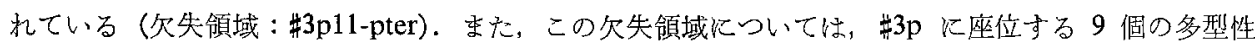
プローブ (D3S4, D3S30, D3S2, H35，D3S11，THRB，RAF1，D3S18，D3S22）荧用いて正常体細 胞（リンパ芽球細胞株）括よび腫瘍細胞の DNA を解析し， 5 個のプローブ（D3S4，D3S30，H35， D3S11，D3S18）について LOH が存在することを確認した.

ヒト正常線維芽細胞由来の \#3p 染色体 (neo 耐性遺伝子で摽識) 1 本をもつマウス A9 細胞から

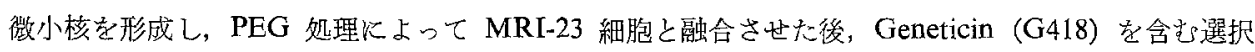
培地 RPMI1640で培責し，5種類のクローン等ることができた。これらのクローンについて，Q分染法によって染色体構成を調べたところ，すべてのクローンに执いて拈染色体が導入されている ことを確認した。 また，融合細胞の形態怙よび in vitro に扝ける增殖性を調べた結果，いずれのクロ

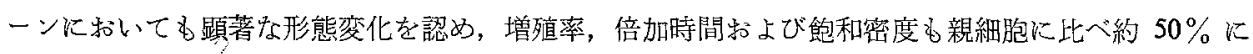
低下していた．また，これら5クローンのうち 2 個のクローンの融合細胞は $2 \sim 3$ 力月の継代培養 後完全に增殖が停止した，一方，刘照として 7 和よび \#11 染色体を同栐の力法を用いて MRI-23 細胞に導入したが，得られたいずれのクローンに扔いても細胞の形態変化ならびに增殖率や倍加時間 の低下は認められなかった，以上の結果，正常細胞由来の邦染色体短腕にヒ下蜸癌細胞の增殖水対 して抑制的に作用する遺伝子が存在すること，また，その抑制遺伝子の消失が腎細胞癌の発生に重要 な役割を果をしていることが強く示惨された。

[発表演題への反応と討論] われわれの穾験データ《関しては，染色体ならびにDNAの両側面から 非常に明確なデータを出しているとの評価を受けた。 また，正常 \#3 染色体が導入された融合細胞の 性状を解析する場合，ヌードマウスへの可移植性は検索していないのかとの質問を受けた．本研究に

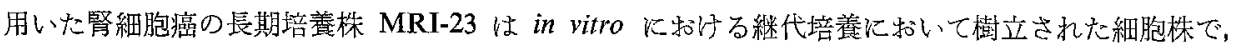
残念なことにヌードマッスへの可移植性は示さなかった。これらの解析結果炕関主る買問の他炕， 


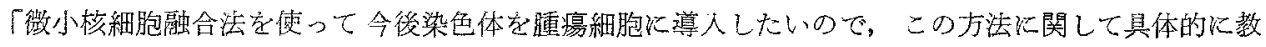
光て涯しい」とか，「現在，実際にこの方法を行っているが微小核細胞を得るためのステップがうを くできないため詳しく教えて经しい」等，技街炕関する間い合わせがいくつか寄せられた。

[関連する他の研究発表等] 今回の国際人類遺伝学会で柱, Plenary lectures, Symposia, Workshops, Slide sessions, Poster presentations 在合わせる己2,883 (抄録が揭載された数) るの演題が発表さ れた。これらの研究発裴のなかで，悪性腫湟以関する発表は，スライド発表 (Cancer Genetics) が 10 題, ポスター発表が Clinical Genetics (Cancer)：42 題, Cytogenetics (Cancer) : 101 題, Molelecular Genetics (Oncogenesis)：44 题，合計 197 題（全演題の約 7\% 弱)でめった.とくに腎細 胞癌の細胞遗伝学的解析および分子遗伝学的解析《関する演題はわれわれの演題を含めて 5 題であっ た. 細胞遗伝学的解析では, Dr. van den Berg 5が, Cell typeをと江した 1986 年の Thoenes \& Stoerkel の分類法によって督細胞癌を 5 つのタイプ (clear cell-, chromophilic-, chromophobic-, ductus Bellini-, oncocytic type) 飞分類し，それぞれてついて染色体異常を解析したところ，\$3 染 色体の哄常は clear cell-type 沉の好観察されたと報告していた。委た，同じ研究グループのDr.van der Hout 5は，\#3p の多型性プローブを用いて腎細胞癌の DNA 解析を行って括り， 3 p21-p24 領

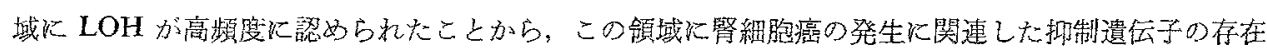
が想定されると述べている。この他に，Dr. Erlandsson らは，\#3p に座位する遺伝子 acylpeptide

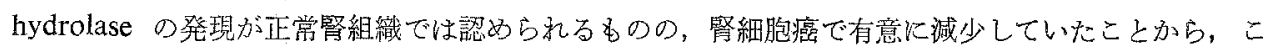

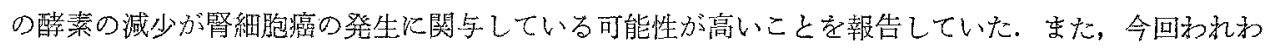
れが用いた微小核細胞融合法と同様の手法によって腫漟細胞の增殖扣制を解析した演題が 1 例発表さ れていた。 Dr. Athwal らによるこの報告では，ヒトの malignant glioma の長期培責細胞飞 \#9 染色

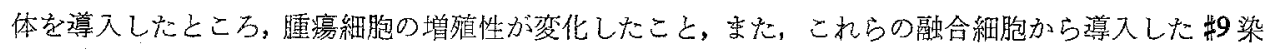

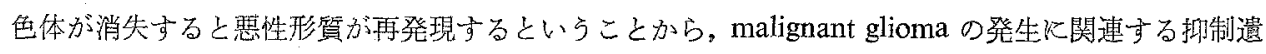
伝子が \#9 染色体に存在するといらことを示していた。さらに，同じグループが，SV40によって不

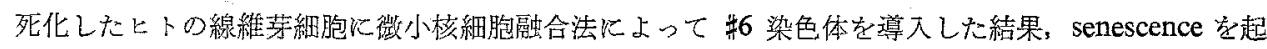

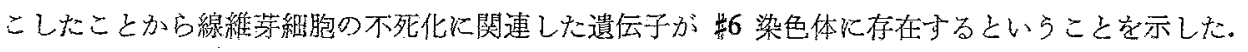

今回の国際人類遺伝学会に提出された演題のなかで，覀性腫痬に関するものはわずかに 7\% 弱で

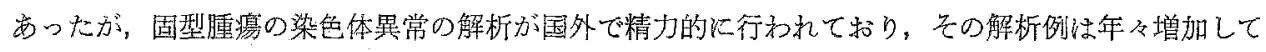

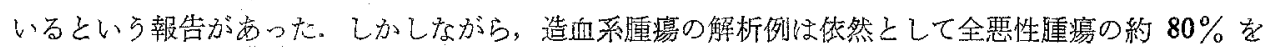

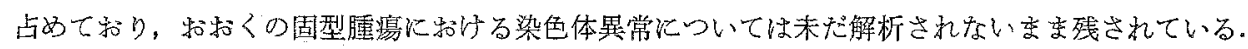

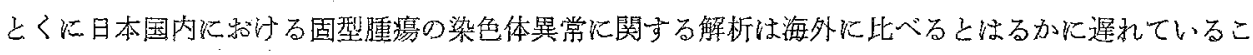
と夌改めて痛感した.

今回，このような貴重な機会を与兄てください未したこと深く感謝致します。

\section{3. 鳥取大学医学部脳幹性疾患研究施設脸神経小坚科部門助教授：大野耕策}

\#798 Mouse model of Niemann-Pick disease : Abnormalities in cholesterol metabolism in the 3T3 cell line are similar to those in cell from Niemann-Pick disease type $\mathrm{C}$ and I-cell disease.

[两究発表の内容] ニーマン・ピック病 C 型は，原因不明の疾患であるが，1984 年アメリカ $\mathrm{NIH,}$

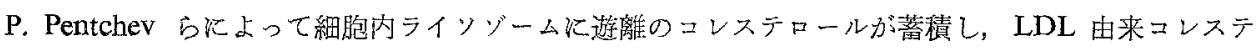
ロールの細胞内でのニステル化樟害があることが報告された。この後，LDLの細胞内取り込みに よって引き起こされるコレステロール恒常性維持のための反応が極めて不良で岁ることから，この疾

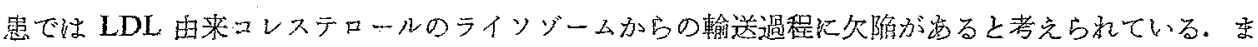


た, I-cell 病でもコレステロロールのエスデル化湆害があることが知られている。一方, sphingomyelinosis (SPM) マウスは日本新薬山科植物研究所・宮脇ら民より発見され，日本大学・北师らとと屯 にニーマン・ピック病のモデルマウスとして報告されている。

われわれは, ヒトニーマン・ピック病 $\mathrm{C}$ 型, A 型, B 型, I-cell 病, 正常人由来の緎維芽細胞と この SPM マウスより永遠の寿命を持った $3 \mathrm{~T} 3$ 細胞株を樹立し, これらについて以下の発表を行った，

1）ヒトニーマン・ビック病 C型細胞で, 酶酸などから合成される内因性コレステロール合成系に 注目し，この系が C 型蛒よび I-cell 病で九進していることを示した。

2)このニーマン・ピック病 C 型の内因性コレステロール合成系の克進は，LDLなど外因系コレ ステロールが有效に利用できない結果と考光，この内因系を阻害する可能性のある薬刘炕対する感受 性を調べたところ，C型細胞と I-cell 病細胞は，ともにビタミン $\mathrm{D}_{8}$ ，ポリェン抗生物質，メバロチ ン烧して異常な感受性を示すことを示した.

3)さらに, SPM マゥス $3 \mathrm{~T} 3$ 細胞株も, ライソゾーム酵素活性, 細胞内遊離コレステロールの蓄 積, 外因泩コレステロールのエステル化障害, 内因性コレステロール合成系の艺進, コレステロール 合成阻害剂飞対する異常感受性のずでての点で，ヒトニーマン・ピック病 C 型に類似していること 示した。

4)これらの点飞より，SPM マウス $3 \mathrm{~T} 3$ 細胞株はヒトニーマン・ピック病 C 型のモデルであり， コレステロール合成阻害剤住する異常感受性を利用することで，こ礼ら特異な細胞内コレステロー ル代謝障害を示す疾患の遺伝的解析が可能になることを示した。

[発表演題への反応と討論] この疾患でコレステロールエステル化障害の存在することを見いだし， この疾患の研究の先駆者であるアメリカNIHのP、Pentchevらと，1)このンステムを用いてのニ一 マン・ピック病 C 型に次損するヒト遺伝子クローニングの可能性の有無，2）SPM マウスとヒトの 型との遺伝的異質性をた，別のモデルマウスとして，Pentchev らによって報告されているCSD マウ

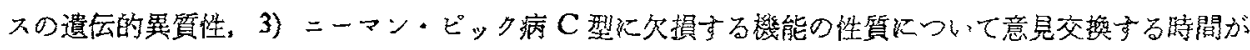
持てたことは, この演影についての討論の最も大きい収檴であり，今後のわれわれの研究にとって大 きい励みとなった。

[発表演題と関係する研究発表の状況] ニーマン・ピック病 C型と関係する研究発表はこの他沈, わ れわれが演題 \#627 (Complementation analysis among 3T3 cells and cells from Niemann-Pick disease type $\mathrm{C}$ and I cell disease.) と演題 $\$ 875$ (Correction of abnormal phenotype by transfer of human chromosome 18.) て SPM マウス 3T3 細胞株の 6TG 耐性株とヒトニーマン・ピック病 C 型を細胞融合し，HAT-ouabain 培地で選択してコレステロール蓄積を見たとを，コレステロール 蓄積が消失し，ヒトとマウスは遺厷的に相補する可能性を示した発表, また SPM マウス $3 \mathrm{~T} 3$ 細胞 のコレステロール蓄積はとト染色体 18 番にあることを示した発表安行りた. Mount Sinai Medical Center $の$ Desnick らによって, $\$ 2491$ (Metabolic correction of Nieman-Pick disease fibroblasts by retroviral-mediated gene transfer) として sphingomyelinase cDNA をモデルマウス細胞に導入 することで, この異常が正常化したことが抄録で記載されモデルマウスはA 型に近い可能性を示㤎 していたが，実際の発表ではモデルマウスについてのデータ快削除されていた。また慈恵会医大の衛 藤らによって, して，日本で発見されたマウスがコレステロールエステル化関して：ニーマン・ピック病C 型に 類似することが報告され，アメリカのモデルマウスと交配することでその黑常が軽減する可能性が示 さ机た。

[その他の尝考事項・感想] 今回の会議を通じて最も印象深かったのは, 遺伝病の研究が cDNAの

Vol. 37, No. 2, 1992 


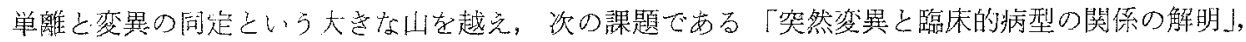

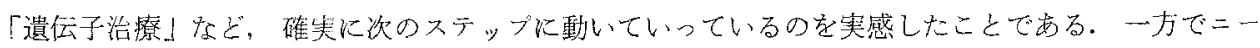
マン・ビック病 C 型は比較的頻度の高い遺伝病であるがその欠損蛋白も明らかでなく、われわれの研

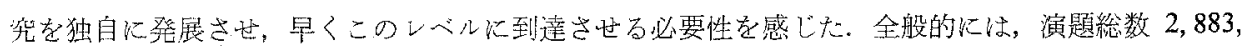
参加者 5,000 人以上とい5大きな学会で, 日本人は決して多くなく, 目本の人類遺伝学の底辺の小さ さ学じな.

\section{4. 熊本大学医学部附属病院小児科：遠藤文夫}

今回日本人類遺伝学会から渡航費用の援助をいただき。ワンントンDCヌンベンションセンターで 開催された人類遺伝学会世界大会に参加することができた，私の主な目的は，1）ここ数年来取り組 んでいるブロリダーザ (peptidase D) 欠損症に関する研究成果について発表するととるに，この分 野の研究者之意見を交換すること，2）コラーゲンの一次的異常に基づく遗伝性疾患の研究の最前線

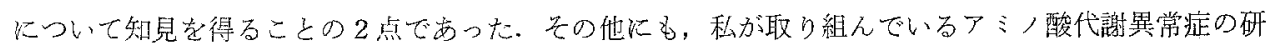

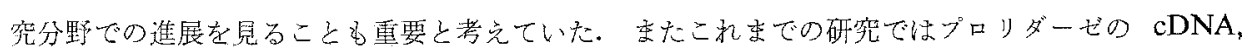

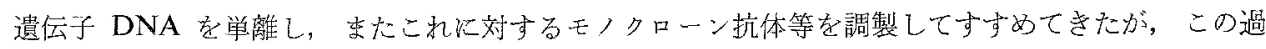

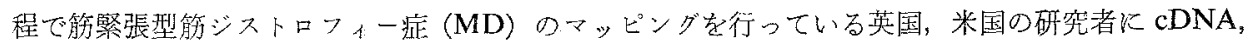
遺伝子 DNA を供給してきたので MD 関する研究の進展にも興味があった。

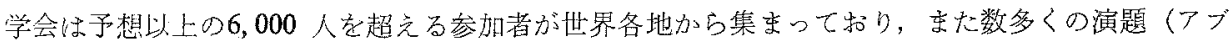
ストラクトは2,883 題）が発表されていた。しかし残念なことに私が研究している分野の研究者の参 加が予想外飞少なく、アミ，酸代謝関倸の演題も少なかった。

私の演題（ポスター）は米国・カナダ，欧州・カーストラリア・日本のプロリダーゼ欠撌症につい

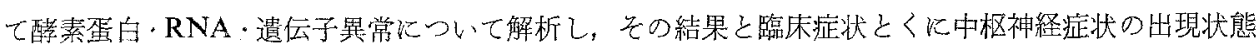
を比較検討したるのであった。オーストラリアの共同研究者（Dr. Danks）は参加していたので，今 回の発表饵いてディスカッションすることがでさた。

マルファン症候群をはじぬとするコラーゲン・フィブリリンに関戛した結合織疾患研究の最近の進 歩について Current workshop: Heritable connective tissue disorders: Molecular and phenotypic correlations で虽れることができた。このセッションはつい最近，マルファン症候群の遺伝子が単離 され笑変巽の同定がなされたため、ブログラムに大さな変更がなされたアアブストラクトの段階で はフィブリリンとマルファン症候群の関係については演題が 1 つ記載されていたが，このセッション の前半部分に，急遽フィブリリンとマルファン症候群に関するトビックが並べられだママルファン症 候群については Nature に揭载されていたと扔りであるが，與味深かったのは，フィブリリンに関連 した（相同性の高い）遗伝子が2つクローン化されていたことで市った。とくにこのなかの1つは， マルファンによく似た疾患で品る congenital contractural arachnodactyly（CCA）との道鎖が判明 していた. ンラーゲンルついてはそのサブタイプの異常にしたがって一群の疾患が記載されてきてい るが、フィブリリンについても類縁の構造蛋白の異常に基の゙く一群の疾患が存在すること走唆して いる結果であった. このセッションの最後は Dr. McKusick が感慨梁く締めくくった.こ机らの研 究で中心的な役割果たしてきた New York, Mount Sinai School of Medicine の Ramirez 教授は

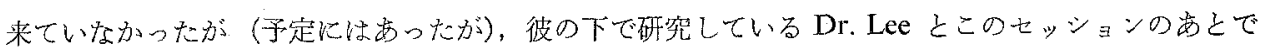

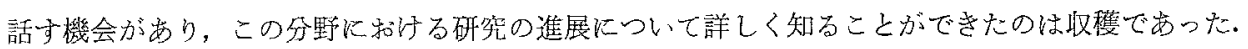

コラーゲンに関連してもらひとつ與味深かったのは遺伝性腎炎 Alport 症候群飞関するDr. Tryggvasonn (Univ. Oulu, Finland) の講演であった (Workshop: Hereditary kidney disease). わ 
れ为光の研究室です最近，日本人 Alport 症候群の遺伝子解析を開始しているが，この学会を機炕 Tryggvasonn 教授と今後の共同研究の話をぬとめることができた。

学会全般をみると，人類遺伝学研究の進展が一段と加速されたのを強く感じた，とくに遺伝子の物

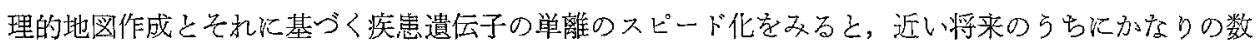
の疾患遗伝子が単離されるるのと考完られる，上述した筋緊張型筋ジストロフィー症の遺位子むすで

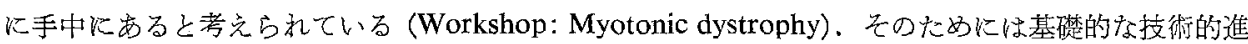
歩もさることながら臨床の分野からみると疾患の均質性や異質性について明確な基準をるうけて整理 していくことが遺伝子単離に重要であるうと考劣られた。遺伝性疾患を直接診療している臨沫分野の 私たらの役割が大きいと言えよう。

今回派遣していただいたことを機にますます努力したいと考光すすとともに，機会を与えていた块 きした松永会長をはじめとする日本人類遺伝学会の皆様汇深く感謝致します。

\section{5. 埼玉県立小児医療センター遗伝科医長 : 福嶋義光}

Are the genes for Aicardi syndrome and Goltz syndrome contiguous? A case of both syndromes with Xp22.3 deletion.

第 8 回国際人類遺伝学会 (ICHG8) の opening ceremony は金管五重奏団（トランペット 2, ト ロンボーン 2, ホルン 1) の演奏で始まった. バッハのインベンションの後, この学会のために作曲 された “Diversions on a Repeated Sequence”（反復配列上の楽しみ）が演奏されれ。礼ごそかなな があはつらつさと華やかさのるる味かい深い曲で，世界各地加ら集まった 6,345 名の参加者（内 professional 3,786 名) の心を和ませるのに十分であった。参加者の過半数はつメリカ国内からであ ったが，他の主な国からの参加者はカナダ 311 名，イギリス 173 名，イタリア 111 名, フランス 103 名, 日本 100 名, ドイッ 95 名, オランダ 86 名, イスラエル 54 名, ブラジル 58 名, フィ ンランド 41 名などであった.

ICHG8 は 5 日間にわたり，2,883 の演題が 98 の sessions 飞分かれて行かれた。はじあにV.A. McKusick が開会の挨拶として，過去 7 回の ICHG を振り返るとともに，現在拈よび近い将来にわ たっての Human Genetics の在り炕ついて, "Medicalized"と "Molecularized”という2 20 key words を示した，前者は人の個体差を研究する学問の一分野であった Human Genetics がすで にさまざまな領域において医療の場に応用されるようになって和り，今後む医療・医学の一部門とし て，大きく発展し，人類の生存と幸福のために役立てられるであるらといらことであり，後都はすで に始まっている分子レベルでの解析がさらに広く深くなされるであるらということであった。

著者の演題は Cytogenetics: Chromosomal syndromes に分類された，この分野の Workshop の 中で D.H. Ledbetter (Baylor Coll. Med., Houston) は segmental aneusomy syndrome (分節染 色体異常症候群）といら概念を提唱した。これは microdeletion syndrome (微細欠失症候群)や， contiguous gene syndrome (血接遗伝子症候群) と同義語であるが，微細な部分モつりミ一や部分卜 リソミーだけではなく genomic imprinting (ゲノム刷り込み) 現象も含むより広い概念である。すな わら染色体上整然と並しでいる遺伝子群のある範围が欠失, 重複, ゲノム刷り込及現象などによっ て障害され発症する疾患群を示す. 本学会では Prader-Willi syndrome (15q11-q13), Angelman syndrome (15q11-q13), Kallmann syndrome (Xq22.3), DiGeorge syndrome (22q11.2), WAGR complex (11p13), Miller-Dieker syndrome (17p13), Beckwith-Wiedemann syndrome (11p15) な ぞが報告され、それぞれの疾患の発症機構の理解が深まった。とくに Beckwith-Wiedemann syndrome では M. Mannens (Univ. Amsterdam) が target locus と control region $11 \mathrm{p} 15$ k想定し, こ 


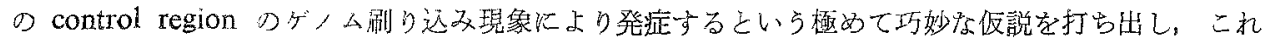
を証明した。

著者が今回報告した segmental aneusomy syndrome（分節染色体異常症候群）に含束机ると思わ

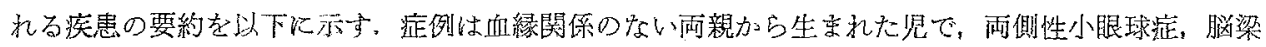

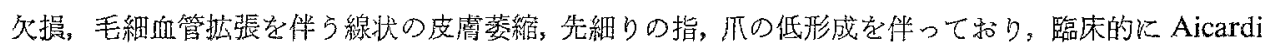
syndrome (AIC) Ł Goltz syndrome (GS) 雨者の症状の一部灾していると考劣られた。染色体 検榃では Xp22.31-pter の佚を認めた，RBG 法によるX染色体の不活化現象の観察では，正常 X

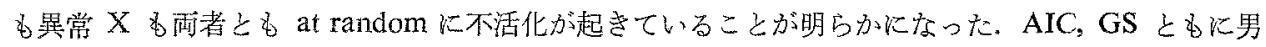

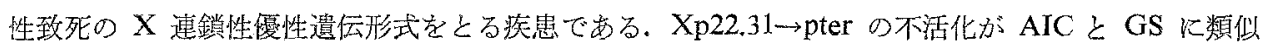
した症状の発生に関与していると考无られた。今後 positional cloning の手法孝用いた AIC, GS 両 痰琶の遺伝子解析加期待される。

この報告に対 L, D. Aughton (William Beaumont Hosp., USA) と E. Myburgh (Univ. van Pretoria, South Africa) 上り，全く同榚の症例があることが示され，Xp22.3 $\rightarrow$ pter deletion, AIC-GS like syndrome の存在が確赛なるのと考えられた。

李た S. Schuffenhauer (Ludwig-Maximilians Univ., Germany) からは，この部分の positional

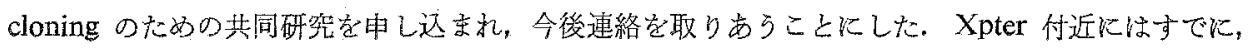

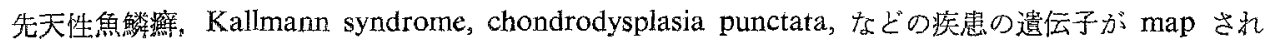
ており，DNA probe 为数多くクローニングされている，多くの研究者加この領域に注目して就り 本症例の molecular level での解析に本領域の characterization に役立つと考克られた. 本症例の患 著・家族の B-lymphoblastoid cell line はすで樹立しているので，幅広く提供することにした。

著者の関係する分野での本学会での最大のトピックスは genomic imprinting(ゲノム刷り达み) 現

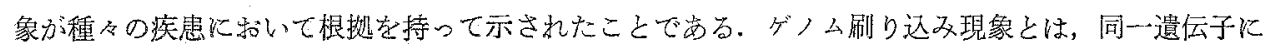

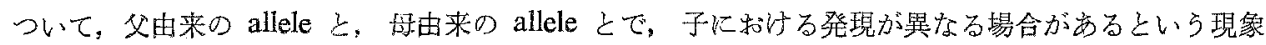
でるるたと常ば，IGF2 (insulin like growth factor 2) gene は，母由来の allele が别り込ま机

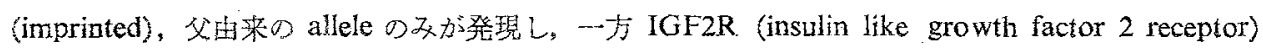
geneは父由来の allele が刷り远をれ，度由来の allele のみが発現していることが，mouseで証明さ れた。こ孙配偶子形成期飞 methylation 厄よる不活化が autcsomes にも起こって和り，その起こ りかたが，精子形成期と訵子形成期で暴なることによると考光られている。この概屾従来のメンデ

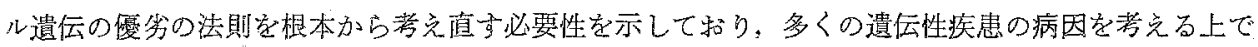
必す念頭に和いて和かなけ和ばならなと思力れる。

最後の plenary lecture で, H. Galjaard は人類の生存についてのさまざまな問題を提示した後,

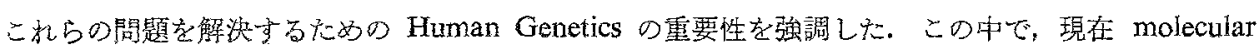
genetics のみ攵注目されているが，molecular genetics の発展は clinical geneticsなど他の分野の協 カなくしては成り立たず，すべての geneticists は Human Genetics の発展炕 contribute す吕機会 があることを逊べた。

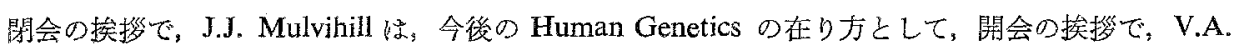
McKusick が述べた 2 つの keywords に加えて, “Internationalized”といら keyword を示した。 これからは Human Genetics の研究炕轧いて，各研究者は估人の策誉を求めるのではなく，Human

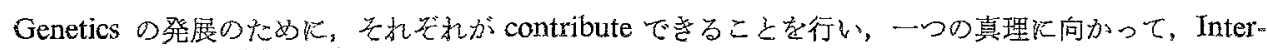
national な共同研究を押し進める必要があることを言った車のである。

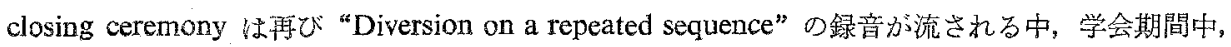


撮影された写真のスライドが次々と示され，参加者全員の拍手と感動のうちに終了した。

本学会で示された Medicalized, Molecularized, Internationalized の 3 つの keywords は日本人 類遺伝学会にとっても重要と思われ，今後この方向で著者も努力ぬ続けていきたい。

\section{V 日本人類遗伝学会教育推進委員会}

本委員会は，全国の医科大学・医学部比和方卒前教育の「大綱化」の機会に人類遗伝学教育の向 上を図るため, 平成 4 年 4 月, 理事長と教育推進委員長の連名で, 学長・学部長涴てて, つぎの 要望を行った。

教務関連委員会・委員長 殿

平成 4 年 4 月

\section{日本人類遗伝学会}

理 事 長 三輪 史朗
(冲中記念成人病研究所長)
教育推進委員長 近藤喜代太郎
(北海道大学医学部公衆衛生学教授)

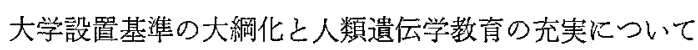

貴殿には益々御健勝のことと和喜び申し上げます。

御存じの通り，文部省は卒前医学教育充実するため，教養課程と医学専門課程の区別をなくして，

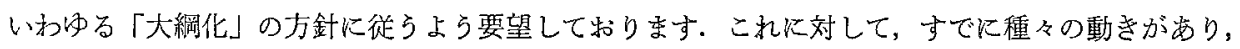
国立大学の場合，第 51 回国立大学医学部長会議ではつぎの申し合わせがなされなした。

1. 大学設置基準の大縌化について

(1) 教育内容・方法炕関する事項

(a) 開設授業科目及び卒業要件 (1) (3)省略

(4) 以上の上うな趣旨から，大学設置基準の開設授業科目及び卒業要件に関する規定は，以 下の方向で改正する必要がある.

ア開設授業科目については，大学設置基準上，一般科目，専門教育科目等の科目区分 は設けないこととし，大学は当該大学，学部及び学科（課程）の教育上の目的を達成する ために必要な授業科目を開設し，体系的に教育課程を編成すること，教育課程の編成に当 たっては，学部等の尃攻に係わる専門の学芸を教授するとともに，幅広く深い教盖，総合 的な判断力を身につけさせ，豊かな人間性を涵養するように適切酒配慮すること。

( 亿以下省略)

国立以外の医科大学・医学部でもこの改正に対応して目下，各々の協議が行なわれている所であり ます。そこで，この機会に当たりまして，日本人類遺伝学会は、かねてから提唱して括りました人類 遺伝学教育の重要珄とその充実につき⿱一兀，学会内外での近年の動きを改めて御報告し，各大学の カリキュラム立案の改訂に当たって，その点について特段の御配意を戴きたく，本信を差し上げる次 第でございます。

近年，日本をはじめ，先進国では，外因性疾患が制圧され，新生児〜小児期の疾患のなかで遺伝性 疾患，発達障害などが重みを增してきました。また多くの国々で，細胞の制御機構の障害とも考えら

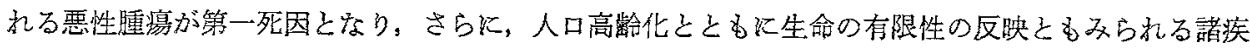


患が重大化しており客す。これらの疾患见は遗伝要因が関与することがきかめて多く，その治療・予 防には遺伝学の知識が不朔欠であります。

このような疾患像の变動を予想し，早くも1962 年に WHO は卒業医学教育で遺伝学が重要にな ったことを指摘し，それを受けてこれまで当学会も再三再四にわたって種なの努力を行なって参りま した。そのひとつとして，1987 年以来，教育推進委員会を設け，様々の角度から検討いたしました。 人類遗伝学は遺伝子とその関連のもと注命現象を研究する学問で，生化学や生理学々並ぶ学科で节 ります。かしこのことは，わが国の医学者の間でまだ充分に理解されているとはいい難いと思いま $\rightarrow$.

貴学におかれましても，园学教育の大綱化にともなって，現在，カリキュラム改訂など，さまざま の問題を御検討中のことと洋察申し上げます、ここに当学会ががてから研究して参りましな結果を つぎの2 資料として御届けし御参考供したく存じて打ります。是非ともこれらの資料を御検討下さ いをすよう，御願い申し上げます。な柾，すで炕高度の人類遺伝学教育を行なっている医科大学・医 学部がござい主すが，本信虫すべての学校卸送り申し上げました。

資料 1. 卒前医学教育力リキュラムに乱外る人類遺伝学のあり方

資料 2. 学会記事・日本人類遗伝学会教育推進委員会

このらち，資料１では，医学教育に和ける人類遗伝学の役割と日本での現状が述べられ，卒業後 10 年後の医師がそれぞれの職務の中でどのような遺伝的問題に出会い，ひいては卒前教育に何を望 屯かを述べて责り亲す。一方，資料 2 には当学会が提案する人類遺伝学の卒前カリキニラム案が揭 げられております。

貴校の益々の御発展を竹新り申し上げます。

（注）資料 1 纯平成元年度 医学教育研究助成成果報告書, 医学教育振興財団 1991, 資料 2 は本誌 $36: 203-209$, 1991.

（文責 近藤喜代太郎）

\section{VI 臨床遺伝学認定医の経過措置による認定のための第 3 回申請について}

人類遗伝学雑誌（以下本婄） 35 卷 3 号に収载の会告汇従って䠛床遗伝学認定医制度に上る第 3 回 認定をします。請の期間は1992 年9月1 日〜30日です.

\section{1. 認定のための申請手続き}

1) 資格：(1)(2)心何礼方

(1) 1985 年度以降の本学会の評議員

(2) i） 1993 年 3 月 31 日から遡って本学会の会員歴が 3 年以上

ii）申請者を筆頭著者々する遗伝医学領域の原著論文が 5 編以上する(3 編までは原著筆 頭論文1編について 2 編の共著論文で替えることができる).

iii）認定医制度施行細則第 6 条汇定める単位が 30 単位以上ある.

2) 認定のための申請方法

（1）会費納入歴の証明：往復はがき（図1参照）で学会事務センターへ少なくとも手続きの 1 カ 月前に問い合わせること，認定医委員会事務局には問い合わせないこと，返信用はがきに自分 の宛名を記入することを志れないこと、ア）事務局加らは会費納入期間を回答するので，との 返信はがきを申請書（第 1 号様式）の裏面に貼付すること，イ）事務局から会費未納の返信が 西ったら，郵便振替を用いて会費を納入し，返信はがきと送金証明のコピーを审請書の裏面に 
貼付すること.

会費納入歴の証明のない場合は申請を受付けませんから，ご注意ください。

（2）審䍒料 $(20,000$ 円）を本誌汇緅じ込及の郵便振替払込用紙を用いて払い込んでください，送 金䛧明のコピーを审請書（第 1 号様式）の裹面に貼付するごと.

(3) 所定の書類（本誌 35 巻 3 号飞経じ込み）飞必要事項を記載し，下記の書類を添えて 1992 年 9 月 30 日穼で認定委員会住出する.

(1) 番査料 2 万円の㕕い込みの郵便振替払込金受領書のコピー（2の襄に貼付）

(2) 認定医認定申請書（第 1 号樣式）

(3) 㠅歴書 (第 2 号様式)

(4) ふだえ使っている履歴書のコピー

\section{2. 履歴書 (第 2 号様式) 記載上の注意}

(1) 学会会員歷

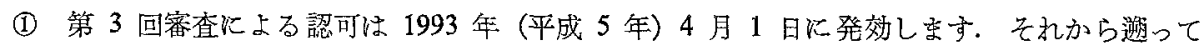
3 年前（1990 年 4 月 1 日）加引き続いて会員であったことを記入すれば充分です. 5 年

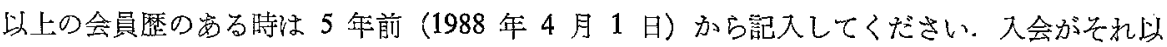
前の場合，正確な入会年月日を書く必要は要りま地んから，入会年月日を学会事務局に問い合 わせないでください.

(2) 過去 3 年の間煺会し，末た大会している場合は，それ以前の会員歴と併せて 3 年以上飞 なるよら，(1)に準じて記載してください。

（2）単位は次ぺージの表を参考にし，30 単位以上になるよう記入すること，原著論文による単 位は除きす、学会出席の証明書柱不要です。学会発表証学会出席と同点数です。

(3) 指導医

第 3 回の審査で認定する認定医の中から指導医を選び，呿覑いする予定です，他学会の認定

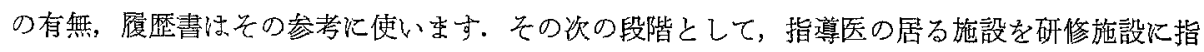
定します。

3. 有効期間

経過措置（暫定制度）の審查は 1990 年度末から毎年 1 回 1993 年度末零で行いすす. 認定の 有効期間岋 1993 年 4 月 1 日 1998 年 3 月 31 日です.

\section{65 歲以上の会虽の申請}

現在 65 歲以上の会員でも認定医を肴望する者は申請してください，認定の有効期間中に 65 歳 に達する会員は 65 藏以下の期間は各年度につき 10 単位の割合で単位を取得してください. 65 歳 に達した以降は単位を取得する必要はすりるせん。認定の有效期間が終り，認定更新の時期（1998 年 3 月）になったら更新兔除申請書（書式は別比定るる）を提出してく代さい。

賽查料の送金先：干755 山口目宇部市小串 1144

山口大学医学部小胃科学教室内認定委員会 [下関 5-17297]

経じ込んである払込通知表を乱使いください，

\section{認定申請書提出先}

厂755 山口罧等部市小串 1144

山口大学医学部小睍科学教室内 認定委員会

Tel. 0836-22-2258

Fax. 0836-22-2257

Vol. 37, No. 2, 1992 


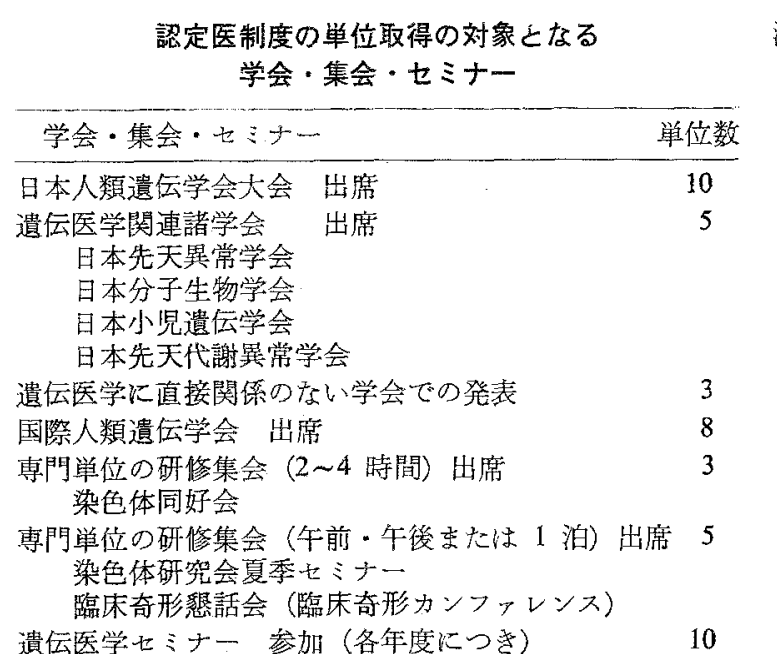

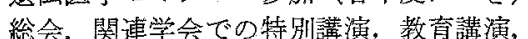
セミナー等の演者, 遺伝医学セミナーの講師 8
注：1）翏定の有效期間(5７年)中に少なく とも1回济日本人類遗伀学会大会火出 席することが望李しい。

2)このリストにない集会・セミナ一はり スト集じて単位を判定，記入するこ 之.

3) 非定期の集含・せミナーを単位として 申請するとさは，その集会・七ミナー つ内容を説明する書類(プログラムの コピー) を添付するるのとする。

4) 一施設・教室内の定期的会合で，外部 飞開放していない娄の(例充ば抄読会) は算位として認め店い。
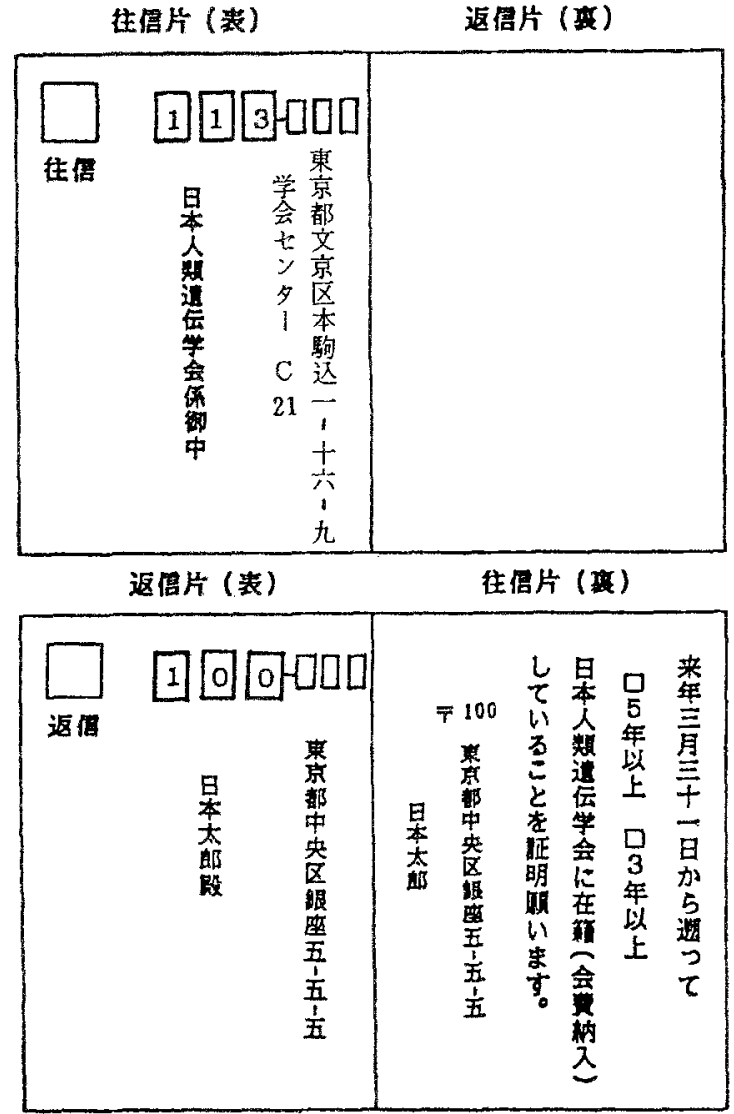

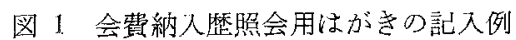
泩：一旦退会して再入会した会曾怔告の旨を 記載する。 


\section{日本医学会だより}

JAMS News

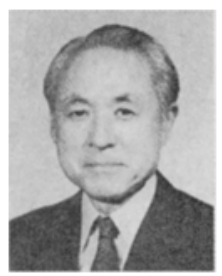

日本医学会長森 亘

\section{森会長就任挨拶}

日本医学会は過去 8 年間，太田会長のもとで着実な発展を遂げてきた。そしてその根底には，日 本医学会の性格を明確にされたこと，また，日本医師会との協調を図りつつ独自の方針を貫かれた ことなどの卓越した基本方針の存在をらかがい知ることができる。

ひるがえって目を外に向けてみると，日本医学会に対する社会からの期待が想像以上に大きいこ

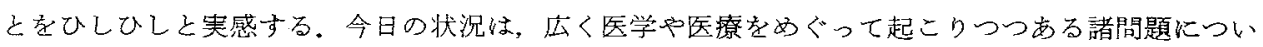
て，日本医学会がどのような姿勢で，どのように行動していくかを考えていかなければならない時 期に来たもの上認識している.

今後, 阿部・小泉・石田各副会長を虫じめとする役員の方々と緊密な連携をとりながら，諸事業 に取り組んでいく所存である，各分科会会員諸氏からも一層のご支援・ご協力を扣願いしたい.

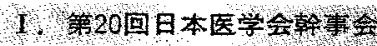

1992 年 2 月 25 日(火), 午前 10 時 30 分から 日本医師会館の会議室で行われた。主として第 59 回定例評議買会に提出する議題の内容が検 討され，その結果，以下の議題が提出されるこ とになった。(1) 1991 年度年次報告, (2) 1992 年 度事業計画，(3)日中医学交流について(4)認定医 について, (5)侌長・副会長・幹事(一部)の選挙,

な挌, 本幹事会では, 報告事項として以下の 項目について説明された。(1)第 24 回日本医学会 総会について，(2)特別シンポシウムの検討委員 会について，(3)日本医学会シンポシウムについ て，(4)医学用語について，(5)日中医学大会につ いて，何認定医について。

交た，次期会長・副会長・幹事選挙について 若干の協議が行われた。

\section{1. 第59回}

1992 年 2 月 25 日(火), 午後 1 時 30 分加的日 本医師会館 3 階小講堂に括いて第 59 回日本医 学会評議員会が開催された。太田会長の挨拶に 続き，以下の議題が取り上げられた。

報告事項として, (1) 1991 年度年次報告, (2)第 24 回日本医学会総会の準備状況.

協議事項として，(1)1992年度事業計画， (2)会長・副会長・幹事の選挙, (3)その他. なお，内容詳細は次のと特りである。

\section{1. 日本医学会役員改選}

本評議員会に颃いて会長以下の役員選挙が行 われ, 会長に森 亘(新), 副会長に阿部正和 (再・臨床部門), 小泉 明(再・社会部門), 石田 名香雄(新・基礎部門)の各氏が選出された。任期 は4月 1 日から 1994 年 3 月 31 日迄である。 
また，幹事の選挙が 2 部会で行われ，黄年徹 (新・第 5 部会)，大越正秋(再・瓶 6 部会)の両

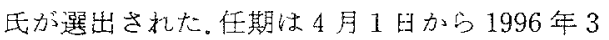
月31日迄である。

その後4月3日に行わ礼た新会舞・副会長に よる第1回協議会で，以トの各氏が会長指名幹 事として在命さ玌た，二浦褚晶(再)，久道 茂 (新)，草間悟(新)，䬦島宗一(臂)，井村裕夫 (再)，森武貞(再)，井口繁(再) 07 名であ 万、任期は，1996年3月 31 日迄である。この結 果, 幹事は非改選者女含为合計16名となった。

2.日中医学大会

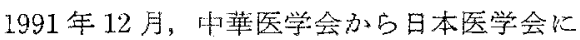
対し，北京で日棵交回復 20 夙年の日中医学大 会を開催したい旨の申し入れがあった。

これ炇し日本医学会としては，主催者とし て名前を逜稀ること位了承するか，実筫的な遇 営には参加できないので，日本側の主体は日中

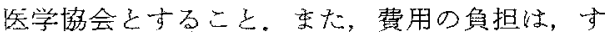
でに本年度予算が確定している等の問题古志 り，日本医学会としては出費不叮能であると回 答し，中華医学会もこれを了我した。京た，太 田前会長から各分科会に刘学協力要請力行初 れた。

\section{3. 第 24 回日本医学会総会の準備状況}

第24回日本医学会総会の飯息等一会頭なら

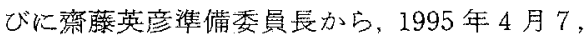
8，903日間，名古屋汸を中心開催が予定 されている上記総会の準備状沅が報告された。

基本テーマは人間性の医学と殹療」サブタ イトルは「生命の世紀をひらく」となったこと， ホたシンボルマーク紹企された、総会準備の 役員す致将決定し，総合㕍示，学術プログラム 等についての基本的な考え方報告された。

\section{4. 医学用語管理事丵}

医学用語管理娄員会の草間委員長から，昨年 4 月に完成した『医学用語辞典况和』に引き 続き, 和英版も1993年の半ばまでに㛡成する 予定で西ることが併过て報告された。

また,外科系の16学会加占日本医学会宛火用
語の統一について要望が来ている点にも触れ， 委員会としてもこの問題に積極的に取り組む誟 えであることを明らかにした。

\section{5. 認定医}

日本医学会屿日本医師会上学会認定医制協議 会に呼びかけて「認定医制についての二者懇談 会」を挂字している。この秘談会について，太 出会長加占，1990年度放 1991 年度の初めの 頃重では制度の検討など順調に進展してきため のの，以後，標榜科目之の強い関連が生してか らは，昘ずしも議論が進展していない，上いう 礐想が述べられた。

\section{6. 複写権センター}

日本工学会老中心として学協会著作権協議会 が複写権センター設立の努力安続け，上らやく, 昨年，闰センターが設立された。日本医学会も 連営資金を出資して運営の中心的な团体の1つ となるよら要請されたが，諸々の事情により， 兒在はまだ参加していない，日本医学会として は，闰センターへの加盟については各分科会の 判断に一任している。

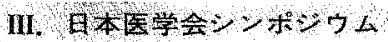

く第 94 回シンボジゥム〉

充度学の進歩一自己免疫老中心䏓一 1992 年 6 月 19 日(金) 日本医師会大講堂 組織委員：尾形悦郎，狩野庄吾，谷口克

く第 95 回シンポジウム〉

小脳一新しい治療法をめざして 1992 年 7 月 31 日（金） 8 月 2 日（日）箱根 組織委員：野令村禎昭，伊藤正男，吉田毙男 (但し，クローズドで行われる)

\section{IV. 特别}

本委員会は昨年10月以設置され，以後 3 回の 討議を経て，概要次のような報告をなとわた。 (1)医学会総会の中間年以開催，(2)東京，京都， 大阪，名古屋以外の地域で開催，(3)テーマは狭 義の「医学」に限定せず，「医学の存在意義」「医 学哲学」などを模索していく，等である。 


\section{日本学術会議だより}

No.24

\section{第15期特別委員会の活動始まる}

平成 4 年 3 月 日本学術会議広報委員会

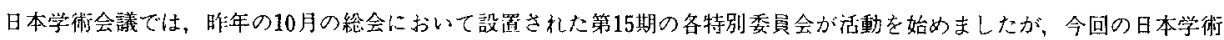
会議だよりでは，これらの特別委員会に放えて、日本举術会議主催 I G B Pシンポジウム等についてお知らせいたします。

\section{第15期の特別委員会}

㫿年 10 月の第 113 回紷会で決定された。目本学術会議の 第15期活動計画では，活動の重点目標として，(1)人類の福 祉・平和・地球環境の重視，(2)基礎研究の重視，(3)学術研 究の国際覚献の重視，の3本の程を指げるとともに，これ らの重点目標老踏まえて，多方面の科学者によって構成さ 机る日本学術会議に心さわしく各分野にわたって広く刘灾 し，かつ第15期中に適切な形で報告・提票に取りまとめる べ顛体的課題として14の課題を選芫している。

具体的課題のうち，今期中に一沁の結論を出すこと加望 ましい臨時的な7つの課題については，それぞれ特別委員 会を設置し，審議を開始した。

各特別委員会の名称次び任枒等は次のとおりである。

文化としての学術

委員長：宅間 去 (第 4 部会員)

(任務) 学術は，人類発展の基礎である。学術研究の意 義についての社会的認識を哚劣るめ，文化とし ての学術の在り方を检討寸る。

平和上安全

委員長：香西 茷 (策 2 部会崱)

(任務) 平和と安全の確保や国際摩擦の解消等心関子る 研究推進の在り方及じ研究体制等について检討す

○死亡医療

委員長：小坂一度見（第７部会夏）

(任務) 医療技術の急速な進展は，自然科学の分野だけ でなく、人文・社会科学の領域に毛種々の問題を 提起している。終末医療に扩引る尊棉死，安楽死 や医療経済の問题，さらに説明と同意などの社会

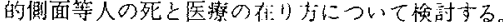

生命科学と社会的諸問題

雬員長：山科郁男 (第 7 部会筫)

（任務）生命科学とその忘用の急速な僬展に伴い，偷理 的，社会的諸問題亚じに规制の在り方等について 検討士る。その際、我加国における生命科学の研 究体制の在り方に电留意方る。

人口・食糧・土地利用

委員長：暒井 功 (第 6 部会員)

(任枒)世界人口の增加や地球環境変化による变糧需給 の不安定化問題と，これらに伴う土地利用変化の 諸影響等を総合的に梌討して，人間活動の在り方 を探る。また，一極集中の激しい我が国の現状を 勘案し，今後の国土利用の在り河ついても梌討 する。
一盗源・エネルギーと地球䍗境

委筫長：哠野正敏(第 4 部会員)

(任務) 資源・エネルギーの開発と利用に伴う自然及び 人闒社会への影譬老研究し、「持続可能な発展」 のための諸方策と環境教育の化り方等について検 討する。

•E大システムと人間

委員長：内山喜久婎（第 1 部会崱）

(任務) 技術革新・システムのE大化が人間に及ぼす影 紫について、安全性確保と人間性尊重の立場から 検討方る。

これらの得特別委員会は，発足以来現存までは各々2-

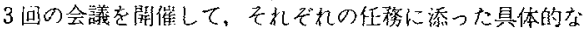

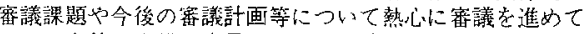

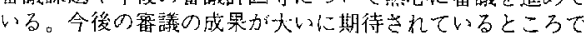
あり，今後，䆺議成果が発表され次第紹介していく予定て ある。

\section{公開講演会の開催状況}

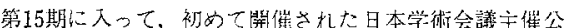
開講演会は，「文明の選推一都市と祳業・農村の共存を目 指してー」と題して，平成 4 年 1 月 27 日 (月) 13 時 30 分 $~ 16$ 時30分に, 福阙明治生命ホール(福阙市)で開摧され，水 間会䝿 (第 6 部)，北村会筫 6 部)及び利谷会員(第 2 部) の講演が行かれ、芕数の聴講者があった。

つづいて，「子どきの人篗を教える」と題して，平成 4 年 3 月 7 日(土) 13 時 30 分 $１ 6$ 時 30 分に，日本学術会議講堂

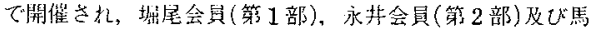

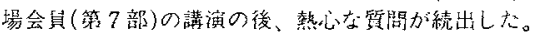

\section{地球圈一生物圈国際協同研究計画 (I G BP)} シシポジウム

日本学術会議主催の地球圈一生物圈国際拹同研究計画 (I G B P) シンポジウム「日本のI G B P 研究の現状と 将来」が去る2月 4 日(火)，5日(水)の酶日，日本学術会議 を会場として開催された。

日本学術会議においては，平成 2 年 4 月の総会に扮いて， 「地球圈一生物圈国際協同研究計画（IＧＢＰ）実施に ついて(勧告)」を採抧し，政府に対し研究の䅡極的な推進 老求めたところであるが，IＧＢＰについて国内の各研究 者，研究機関に打いて笑施される研究の促進を园るととも

Vol. 37, No. 2, 1992 


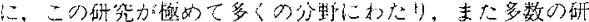
究機洋が関与していることから,この研究の連絡, 調整を 汹る壊として、本シンポジ穴開催することとしたもの であるまた，我が国のIＧBPの砄究が，広義のモンス ーン・アジア地城，伍太平洋地域，椣域を中心に行わ礼る

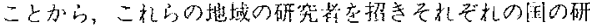

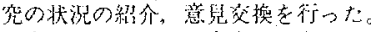

本シンポジウムの内容は次のとおりである。 [1日目]

講 㴼 I GBPEついて

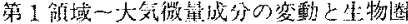

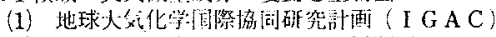

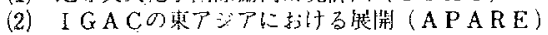

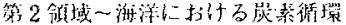

(3) 海洋における炭素僻䅛

第 3 領域一地球変化に保力る生態柔及び水循摆

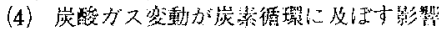

(5) 水得環と生態系 ( B A H C )

第 4 領域〜地球圈一生物圈の机后作朋を考慮したモデリン グ

(6) 父候玉デル扩よび大父化兴モデル

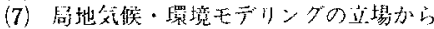

(8) 生態系モデリングの点埸から

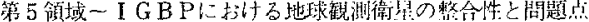

(9) 気象郝星デー夕の現状と捋来

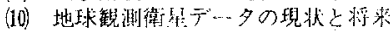

(11) NASA EOS $r$ ASTER

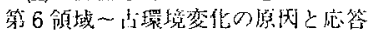

(12) PAGESについて

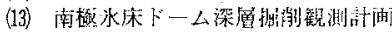

(14) 滥暖化と沿岸塄境

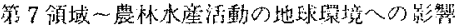

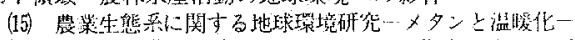

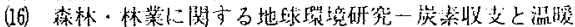
化の柳制 [ 2 日目)

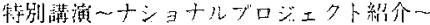

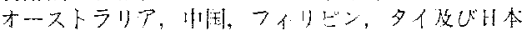

領域別㑑別融議

第 1 领场加施第 7 檚域まで

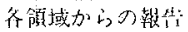

総合討梌

当日は2日閐にわたるシンボジウムで而ったが 300 人老 超之る参加者が苏り，盛测のうち終了した。

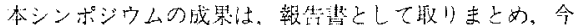

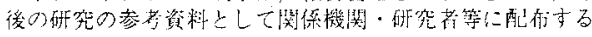
こととしている。

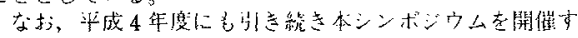

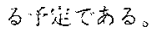

\section{二国間学律交流事業}

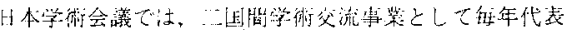

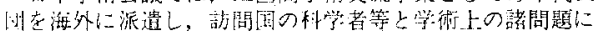

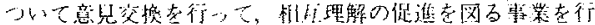
, ている。

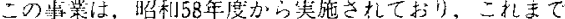

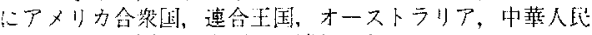
其和国等19加国に代蒜四を派嚾してきた。

平成 3 年度法，11月 4 日か放14日までの11日䦓の日程で

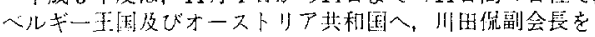

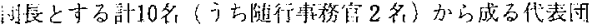
在源禹した。

ベルギー王国では、科学技術强当省、科学、文学及び落

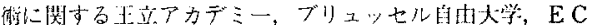

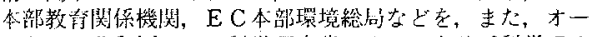

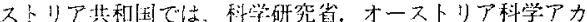
デミ一, ウイーン大学，ドナウ河畔の[国連都术にある国際

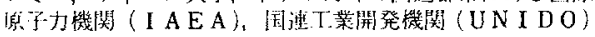
などを訲閣した。

各訪問先では，関保者との間で，それぞれの国の学術研

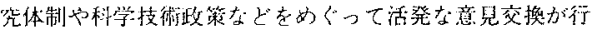
か扎心。

特に印象的だったものとして，まずベルギ一王同では， ECが推進しているERASMUS計画，二狄は E C Action Scheme for the Mobility of University Students $の$ 略で, E

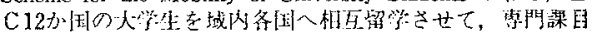

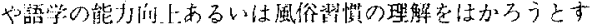
るもので，ECの将来に大きく兒献する电のと思われる。

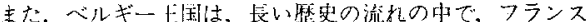

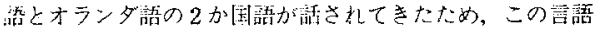

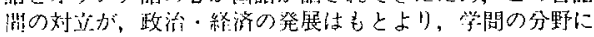

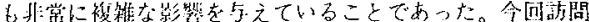

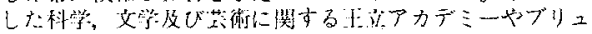
，七ル直由大学毛まったく间名のアカデミ一と大学がフ

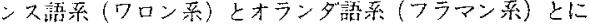
分加机て存在しており，我々の代表団も，间編成を 2 班に 分けてこれらの機関在訲閣守ることになった二とは，非常 に印象的であった。

オーストリア期和国では，650年の伀紌をはこるウィー

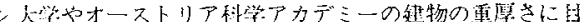
を真はり，またドナウ河畔に作ら机た国連都市にI A E A

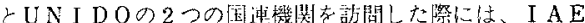
Aのチェルノブイり原発事故以後の核間题への程極的な取

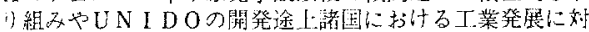

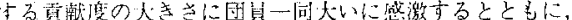

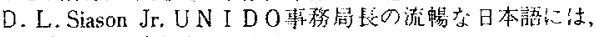

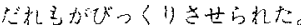

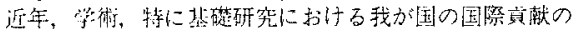

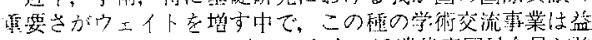

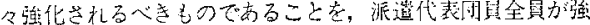

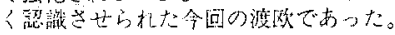

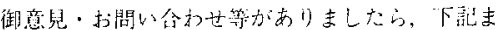
で㧍釘せください。

干106 束尔都榄区兵本朴 7-22-34

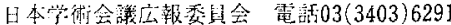




\section{日本学術会議だより}

$\mathcal{N} 0.25$

\section{学術国際貢献特別委員会設置される}

平成 4 年 5 月 $\quad$ 日本学術会議広報委員会

日本学術会議は，去る4月15日から17日まで第 114 回総会（第15期 3 回目の稔会）妾開催し，新たに「学術国際貢献特別 委員会」を設置しました。今回の日本学術会議だよりでは，同総会の議事内容及びろ月に開催されたA A S S R E C執行委 員会等についてお知らせいたします。

\section{旧ソ連邦の科学者に対する㹂急の支援 措置について（会長談話）}

平成 4 年 2 月 25 日 日本学術会議 会長 近藤次郎

ソ連邦か解体したことに伴い、旧ソ連邦における多くの 科学者は, 研究の継続が困難となり, 研究組織も崩藵の危 機に直面していると伝えられており，これが事実とすれば， 世界に与えるその影響は計り知れないものがあると思われ る。

いうまでもなく，人類の進歩にとって科学の向上発展は 不可欠のものであり，その意味で，今日の旧ソ連邦の実情 は夏慮に堪えないところである。

この際，我々日本の科学者は，学協会等を通じる等の力 法で，旧ソ連邦の科学者に対し，能う限りの支援を行う必 要があると考之る。

なお，旧り臬邦の科学者と我が国の料学者との間の一般 的な国際学術交流・協力をより一層充奏するな奻の方策等 については，我加国の学術の分野に㧍汁る国際貢献の一環 として，日本学術会議において引き続き梌討することとい たしたい。

(注)

本談話は，日本学遇会議において国際交流・協力問題に ついて調查・䆺議を行っている第 6 常置委員会から 2 月 14 日(金の連合部会に問題提起され，各部会で㭘討され車議を 経た後，2月25日(灿の)第 785 回運営審議会に提亲され審議 されたものである。

\section{日本学術会議第114回総会報告}

日本学術会議第 114 回総会（第15期 3 回目の総会）は, 4 月15日〜17日の3 日間開催された。
第1日（4月15日）の午前。まず，会長からの前回絵会 以後の経過報告及び各部・各委員会等の報告が行かれた。 次いで，今回総会に提案されている2案件について，それ ぞれ提案説明がなされた後，質疑店答が行われた。

第 1 日の午後。各部会加開催され，午前中に提案説明巳 れた総会提案案件の賽議が行われた。

第2 日（4月16日）の午前。前日提案された案件の番議 ・採決が順次行われた。

まず，「副会長世話担当研究連絡委員会の運裳について (由合せ）の一部改正」が採択された。これは、「副会長 世話担当研究連絡委員会運営協議会」という名称を「複合 領域研究連絡委員会運営協議会」に改めるとともに，運営 協議会のより円滑な運営を図るために，必要な措置を講じ たものである。

次いで,「学術国際貢献特別委員会の設置について（申 合せ〉」が採抧された。これは，学術の分野における我が国 の国際貢献の在り方について検討するた的の特別委員会を 設置したものである。

なお，審議・採決の終了後，さきに会長談話として発表 した「旧ソ連邦の科学者に对する緊急の支援措置について (平成 4 年 2 月 25 日)」に関連して，旧ソ連邦の科学者の実 情調查のために，当会議加らロシアに派遗された第 6 常置 委員会幹事の宅間会員から，五の調查結果について報告が 行われた。

第 2 日の午後。各部会が開催され，各部における臆案事 項について審議が行われた。

第3日（4月17日）午前には，各常置委員会が，午後に は，各特別委員会がそれぞれ開催された。

\section{学術国際貢献特別委員会の設置}

本会議は，昨年10月に開催した第 113 回総会における内 閣官房長官からの学術の分野に扩活る我が国の国際貢献の 在り坊につての検討依頼を踏ま之，今回の第 114 回総会 において学術国際貢献特別委員会を設置した。 


\section{AASSREC執行娄員会の開催}

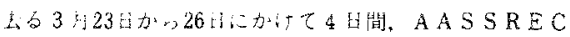
Association of Asian Social Science Research Counc

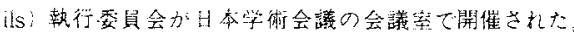

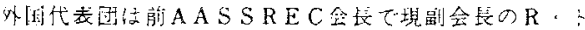

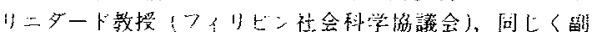

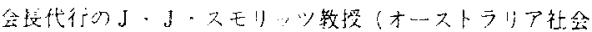

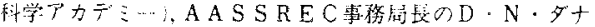

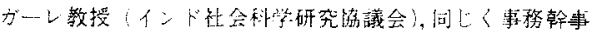

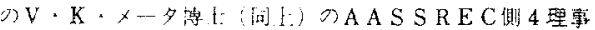

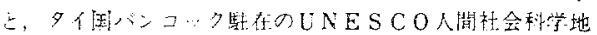

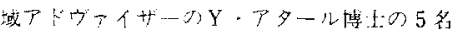

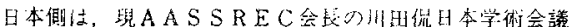

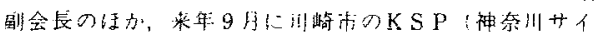

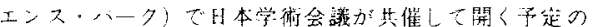

A A S S R E C 第10回日本総会」の組織運営委是会委崱長

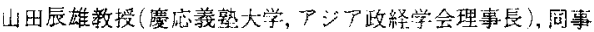

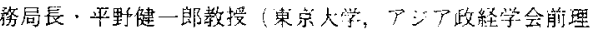

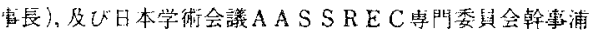

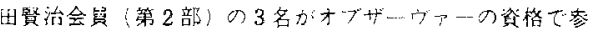

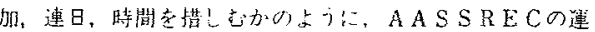

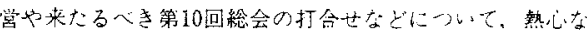
封議方続叮以能た

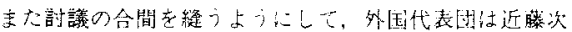

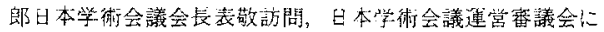

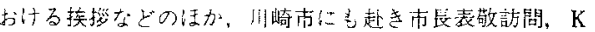
SP視察などを精力的に行った。目本学術会議も，近藤会 铱主幸のレナプションを催し、関保諸国の東京䮦在大使館

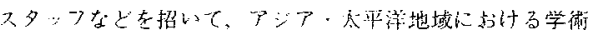

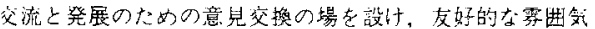
カなかで談諭が風発，至るところで笑の花か開いな。

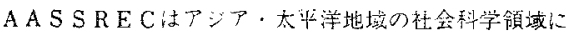
おける国際学徤上部組織て，いか内るアンブレラ・オーガ ニゼイシミンである。1973年にイントのシムラで社会科 学の教育・研究に咸するアシア会議」力開加れた際に設立

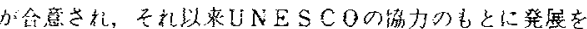

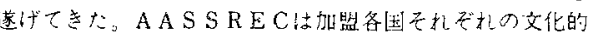
伀統を尊重しつつ、社会科学の研究，教育，知識の普及方

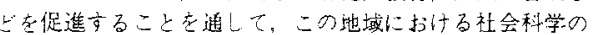

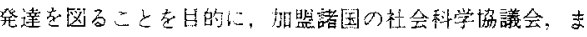

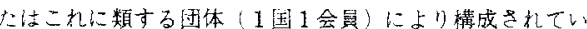
3

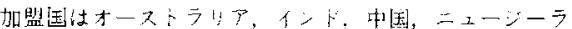

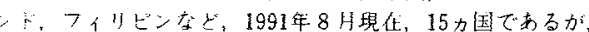

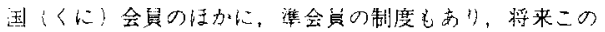

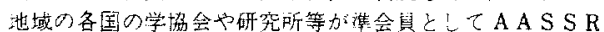
ECの活動に参加する道も算加れている。出版活動として 沈，冽年に開摧される稳会における諸報告やシンポジウム などの出版の活か，定期刊行物「aassrec panorama」が年 2 回出ざせている。

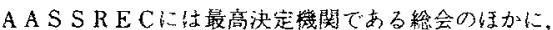
会长, 副会長 ( 2 名制), 事務居長の4名で構成される理事 会が置かれているか。二れにさ的にUNESCOの地域》

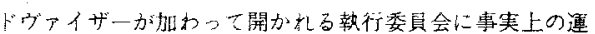

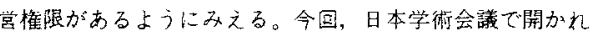
た会議はAAS SRECとしては檚的て重要な会議であっ たといえる。AASSREC注UESCOによって承認

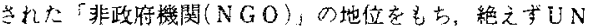

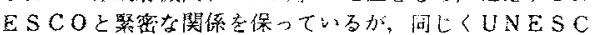
Oによって承諗导れたNGOの地位をるつIFSSO〈国 祭社会科学団体連盟) と正相在協力関係にある。

\section{平成 4 年(1992年)度同主催国際会議}

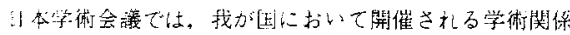

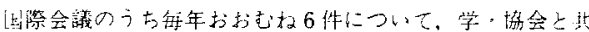
[い]主嬥している，

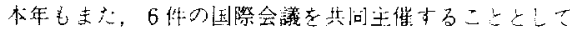

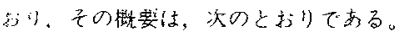

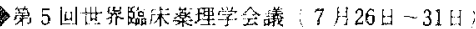

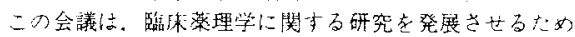

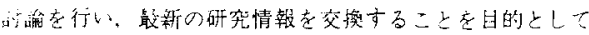

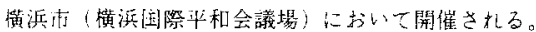

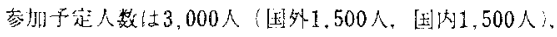

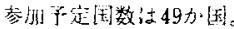

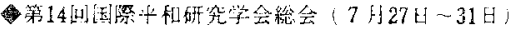

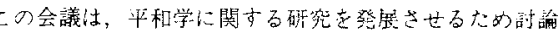
そ打い，最新の研究情報を交換することを目的として京都

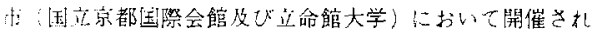
b

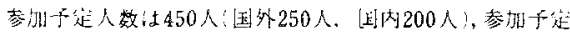

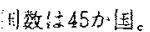

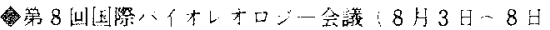

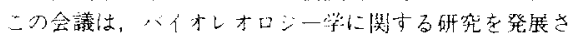
せるた砷諭を行い，最新の研究情䇉を交换することを目

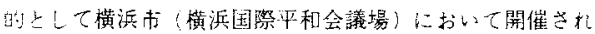
る

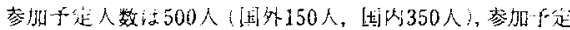
经擞は26力固。

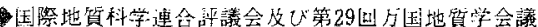
(8月24日 -9 月 3 日)

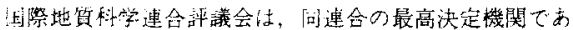

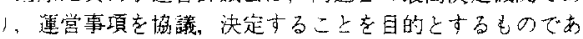

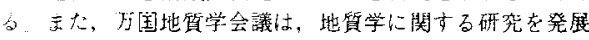

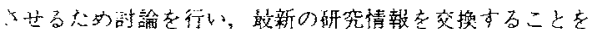

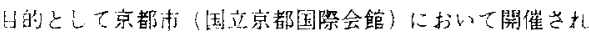

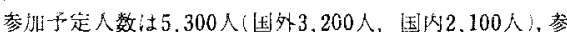
打开䇥国数は94加国。

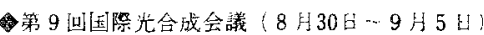

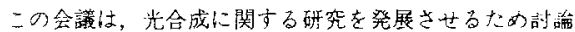
タ行い，最新の研究情報を交換するこ上を目的として名な

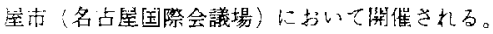

参加予定人数仕1,000人（国外500人，国内500人），参加 f这国数注 41 力国。

第11回国際光生物学会崒 (9月7日-12日)

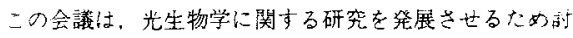
确壳行い，最彩の研究情報を交换古ることを目的として京 都市(国立京都国際会館) に颃いて閶催さ好る。

参加予恶人数は 1,000 人（国外 600 人，国内 400 人)，参加 F䇥国数は52力国。

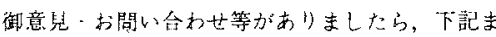

でお筒せください。

干106 案宗都港区六本本7-22-34

日本学術会議広報娄員会 電話03(3403)6291

Ipn I Human Genet 